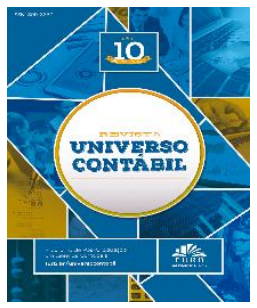

Revista Universo Contábil, ISSN 1809-3337

Blumenau, v. 12, n. 4, p. 107-128, out./dez., 2016

doi:10.4270/ruc.2016430

Disponível em www.furb.br/universocontabil

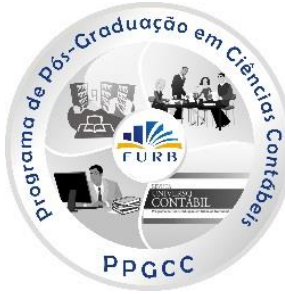

\title{
NON-AUDIT SERVICES AND AUDITOR INDEPENDENCE IN AN ENVIRONMENT OF LOW INVESTOR PROTECTION ${ }^{1}$
}

\section{SERVIÇOS EXTRA-AUDITORIA E A INDEPENDÊNCIA DO AUDITOR EM UM AMBIENTE DE BAIXA PROTEÇÃO AO INVESTIDOR}

\section{SERVICIOS DE NO-AUDITORÍA Y LA INDEPENDENCIA DEL AUDITORIA EN UN PAÍS CON BAJA PROTECCIÓN DEL ACCIONISTA}

\author{
William Brasil Rodrigues Sobrinho \\ Federal Institute of Education, Science and Technology of Tocantins - IFTO \\ Address: Cj 01 Lote 08, Joaquim Teotônio Segurado Ave, Qd 202 Sul, ACSU-SE 20 \\ Zip Code: 77020-450 - Palmas, Tocantins, Brazil \\ E-mail: williambrasil@gmail.com \\ Phone: +55 (63) 3363-9700 \\ Patricia Maria Bortolon \\ Accounting Department \\ Federal University of Espírito Santo - UFES \\ Address: 514, Fernando Ferrari Ave, Goiabeiras \\ Zip Code: 29075-910 - Vitória, ES, Brazil \\ E-mail: patricia.bortolon@ufes.br \\ Phone: +55 (27) 4009-2794
}

\begin{abstract}
This paper aims to evaluate whether the provision of non-audit services (NASs) affects external auditor independence in an environment characterised by low legal protection of minority investors and a high concentration of ownership and control. Audit reports and costs of services are analysed over 3 years for 154 Brazilian companies. The binary variable proxy for independence indicates a qualified auditor's report and, as an alternative specification, the issuing of a going concern opinion. Logit models were employed with control variables to identify aspects related to other sources of threats to independence, management influence, and the effort and risk of auditing services. The results indicate that the provision of NASs does not affect auditor independence. This evidence is robust in terms of the alternative specification of the independence proxy and the observation of a subset of companies considered qualifiable. Only when summed to audit fees is there evidence of a negative impact on independence, signalling that the client's economic dependence might be more relevant than NAS with respect
\end{abstract}

\footnotetext{
${ }^{1}$ Artigo recebido em 01.09.2016. Revisado por pares em 17.12.2016. Reformulado em 21.12.2016. Recomendado para publicação em 21.12.2016 por Paulo Roberto da Cunha. Publicado em 23.12.2016. Organização responsável pelo periódico: FURB.

Acknowledgments: We gratefully acknowledge the financial support of Coordination for the Improvement of Higher Education Personnel (Capes).
} 
to auditor independence. This result is robust to both independence proxies and the subset of qualifiable companies. In general, other sources of threats do not seem related to independence. This study provides evidence of a market in which auditor independence is expected to be compromised, given controlling shareholders' influence on company management.

Keywords: Audit fees; Non-audit services; Auditor independence; Corporate governance.

\section{RESUMO}

Este trabalhou avaliou se a prestação dos serviços extra-auditoria afeta a independência dos auditores externos em um ambiente caracterizado pela baixa proteção legal aos investidores minoritários e com alta concentração de propriedade e controle. Foram analisados os relatórios de auditoria e os valores dos serviços extra-auditoria de 154 empresas brasileiras com ações negociadas em bolsa, durante 3 anos. A proxy de independência evidencia a modificação da opinião do auditor e alternativamente a emissão de ressalva a continuidade da firma. A relação entre os serviços extra-auditoria e a independência do auditor é analisada através de modelos logit. Os resultados indicam que a prestação de serviços extra-auditoria não afeta a independência do auditor. Esta evidência é robusta inclusive em análise da ressalva de continuidade da firma e no subconjunto de empresas consideradas ressalváveis. Apenas quando adicionados os honorários de auditoria, há a evidência de um impacto negativo sobre a independência, sinalizando que a dependência econômica do cliente pode ser mais relevante do que os serviços extra-auditoria em respeito à independência do auditor. Este resultado é robusto para ambas as proxies de independência e inclusive no subconjunto de empresas ressalváveis. Em geral, outras fontes de ameaças não estão relacionadas com a independência. Este estudo fornece evidências ao mercado de que a independência do auditor pode ser comprometida, uma vez controlada a influência dos acionistas na gestão das companhias.

Palavras-chave: honorários de auditoria; serviços extra-auditoria; independência do auditor; governança corporativa.

\section{RESUMEN}

Este trabajo tiene como objetivo evaluar si la prestación de servicios de no-auditoría (NAS) afecta a la independencia del auditor externo en un país caracterizado por una baja protección jurídica de los accionistas minoritarios y una alta concentración de la propiedad y el control. Los informes de auditoría y los costos de los servicios se analizan más de 3 años para las 154 empresas brasileñas. El variable binaria para la independencia indica el informe de un auditor calificado y como una especificación alternativa, la emisión de una preocupación de continuidad del negocio. La relación de los servicios de no-auditoría y la independencia del auditor se analiza mediante modelos logit. Los resultados indican que la prestación de NAS no afecta la independencia del auditor. Esta evidencia es sólida en términos de la especificación alternativa de la representación de la independencia y la observación de un subconjunto de empresas considerados calificables. Sólo cuando se suman los honorarios hay evidencia de un impacto negativo sobre la independencia, lo que indica que la dependencia económica del cliente podría ser más relevante que NAS, con respecto a la independencia del auditor. Este resultado se mantiene tanto las delegaciones de la independencia y el subconjunto de empresas calificables. En general, no parecen otras fuentes de amenazas relacionadas con la independencia. Este estudio proporciona evidencia de un mercado en el que se espera que la independencia del auditor que se vea comprometida, dado que controla la influencia de los accionistas en la gestión de la empresa.

Palabras clave: honorarios de auditoría; servicios de no-auditoría; independencia del auditor; Gobierno corporativo. 


\section{INTRODUCTION}

Auditor independence is a topic debated both by regulators and academics and is an important attribute if the external auditor (ANTLE, 1984). Auditor independence ensures objectivity, impartiality and a lack of bias when drawing up a report on the client's financial statements. Rules stipulated by regulators demand auditor independence to guarantee "professional scepticism". Although the literature argues that auditors have incentives to remain independent (WATTS; ZIMMERMAN, 1981), past events, such as the Enron case, reinforce the need for discussion and research on this subject.

Discussions regarding factors that can lead to reduced auditor independence focus particularly on the provision of advice or consulting services, referred to here as non-audit services (NASs). One of the arguments about decreased in auditor independence is based on the premise that at some point, the auditor might need to perform an auditing procedure on a transaction arising from the provision of NASs. This necessity could result in the auditor's objectivity being reduced and the impartiality of his report being compromised.

Economic dependence on a client and the length of the relationship are also considered factors that can reduce auditor independence. By contrast, the auditor has an incentive to maintain independence, given that building his market reputation requires him to provide a good service over a long period of time.

Auditor quality is an intrinsically unobservable variable, except for situations involving failure. Chadegani and Mohamed (2014) revise the proxies in the literature that measure this quality. In this context, measuring auditor independence is an important research challenge. Studies that use the auditor's report as a proxy for independence generally consider it a binary variable (0/1) that identifies qualified opinions (CRASWELL, 1999) or changes attributable to the violation of the going concern assumption (SHARMA; SIDHU, 2001). Other studies, however, work with the magnitude of discretionary accruals or the likelihood of meeting earnings benchmarks (ASHBAUGH; LAFOND; MAYHEW, 2003).

The auditor's opinion is related to various factors, including the provision of NASs (CALLAGHAN; PARKASH; SINGHAL, 2009; CRASWELL, 1999; DEFOND; RAGHUNANDAN; SUBRAMANYAM, 2002; HAY; KNECHEL; LI, 2006; WINES, 1994), accruals (FRANCIS; KRISHNAN, 1999), the relevance of audit fees (or economic dependence on the audit firm's client) (CHEN; SUN; WU, 2010; LI, 2009; REYNOLDS; FRANCIS, 2000), the length of the auditor-client relationship (GEIGER; RAGHUNANDAN, 2002) and earnings management (BUTLER; LEONE; WILLENBORG, 2004).

To date, there is no consensus in the academic literature regarding how the auditor's independence can be compromised by providing NASs. There is evidence to support the hypothesis that the provision of these services reduces auditor independence (SHARMA; SIDHU, 2001; WINES, 1994); there is also evidence against that hypothesis (CRASWELL, 1999; DEFOND; RAGHUNANDAN; SUBRAMANYAM, 2002).

Most previous studies that analyse the relationship between the provision of NASs and compromised auditor independence have focused on developed capital markets. In Brazil, the capital market is characterised by weak legal investor protection, which is typical of countries with a civil law regime, combined with a concentrated ownership structure. Consequently, the predominant agency problem is conflict between majority and minority shareholders.

Management's influence on audit firm selection and the possible impact on the auditor's independence is the subject of research by Dhaliwal et al. (2015). Although those authors find evidence of managerial influence on audit firm selection, even after Sarbanes-Oxley Act of 2002 (SOX), there was no consistent evidence of compromising independence. In a sample of 400 Brazilian companies, $65 \%$ have a controller that has more than $50 \%$ of the vote (STERNBERG; LEAL; BORTOLON, 2011). Even among companies that lack a controller, 
shareholder agreements that regulate voting rights, among other provisions, are common. The presence of a controller affects the company's management, with the participation of its representatives both in the executive office and on the board. In our sample, for example, slightly more than $20 \%$ of the observed board members are independent. These characteristics create the expectation of a closer relationship between the independent auditor and company management that might compromise independence. In this scenario, the analysis of the effect of non-audit services on auditor independence becomes more relevant.

Conversely, in Brazil, because of the Brazilian Securities Commission's (Comissão de Valores Mobiliários - CVM) 308/1999 rule, which is one of the threats to independence identified in the literature, the long-term relationship, is avoided. The rule establishes the mandatory rotation of independent audit firms every 5 years, with a minimum term of 3 years before rehiring (i.e., a cooling-off period). Mandatory rotation was relaxed between 2009 and 2011 through CVM Resolution 549/08 to avoid harming the work of companies adhering to international accounting standards, which had been mandatory since 2010. The choice of Brazil as the study environment allows the investigation of auditor independence without the effect of the threat to the long-term relationship. In our sample there were no cases in which this rule had been violated.

This research became feasible only after CVM Instruction 480/09, which mandated the disclosure of a report known as the Reference Form (RF), which has a very broad information base. The mandatory information to be disclosed includes the amounts paid to audit firms related to audit fees and other provided services (COMISSÃO DE VALORES MOBILIÁRIOS - CVM, 2009).

For those interested in this subject, the Brazilian capital market, therefore, provides an opportunity to obtain a better understanding of potential threats to auditor independence in a very different environment than the more developed capital markets.

In this context, this study aims to provide empirical evidence of the association between the contracting of NASs and auditor independence.

The proxies adopted to evaluate auditor independence were the qualified audit report and the going concern opinion. Other possible sources of threat to auditor independence e.g., tenure Johnson, Khurana and Reynolds (2002), being in the initial years of contracting DeAngelo (1981) and being rehired after the cooling-off period are controlled. The possible influence of large shareholders or management on auditor independence is also evaluated through corporate governance mechanisms known as methods of reducing conflicts of interest between controlling and minority shareholders. The percentage of independent members, having different persons in the CEO and chairman of the board positions, the presence of an audit committee and being listed on the new market, the most demanding corporate governance segment of BM\&FBOVESPA are control variables in this study's models.

This study does not show that auditor independence is compromised by NASs. The results are robust both to different proxies for independence and to a sub-sample of qualifiable companies (more indebted and with losses). However, when NASs are summed to audit fees, our results show a negative impact on independence when the complete sample is observed, but not in the sub-sample mentioned. These findings may signal that instead of NASs, economic dependence could be a source of concern (CAHAN et al. 2008)

This study's main contributions rely on observing an environment that is different from previous studies, characterised by weak legal investor protection and control concentration, enhancing threats to audit independence through controlling groups' influence on management. The research observes the impact of NASs net of many other sources of threats mentioned in the literature, including tenure and low-balling during the first years of a contract. Management and large shareholder influence is controlled, observing some good corporate governance practices that are recognised as ways to reduce the influence of these groups. Our results also 
have the potential to be useful both to market regulators and to the auditing community during the preparation of guidelines for this profession in the Brazilian capital market.

\section{THEORETICAL FOUNDATION}

The following sections review the existing literature on the subject and present the research hypothesis.

\subsection{The Role and Quality of Auditing in Capital Markets}

Capital markets require precision, reliability and objectivity in relation to accounting data because such data are used as a basis to evaluate company stock (GRAMLING; RITTENBERG; JOHNSTONE, 2012). Accounting allows the reduction of a firm's agency costs, and the disclosed financial reports must be monitored. In verifying that the figures referring to contractual terms were calculated using accepted procedures, the external audit becomes a contract monitoring mechanism (WATTS; ZIMMERMAN, 1986).

Watts and Zimmerman (1986) consider the audit firm's reputation to be a valuable asset. Although it is expensive to establish a reputable history, once consolidated, that reputation tends to increase the demand for the firm's audit services, and consequently, its fees also increase.

The loss of audit firm Arthur Andersen's reputation because of its role in the Enron scandal has led to articles that analyse the effect of this loss on companies audited by that firm. The results of Barton (2005) support the hypothesis that the most visible clients are more susceptible to the auditor's reputation and will more quickly replace Arthur Andersen. In another study based on the same event (the collapse of Enron), Cahan et al. (2013) find evidence that market analysts revised their forecasts downwards to a greater extent, for companies audited by Arthur Andersen than for companies audited by the other members of the Big 4 during the same period. Concern about the auditor's reputation appears to be consistent with the loss of Arthur Andersen's clients in the months following the Enron collapse (DEFOND; RAGHUNANDAN; SUBRAMANYAM, 2002).

According to agency theory, the external auditor is required both to express an independent opinion on a firm's financial statements and to monitor and supervise management actions (FIRTH, 1997). Moreover, managers are incentivised to hire independent external auditors to reduce agency costs (JENSEN; MECKLING, 1976). A lack of auditing credibility and independence may impose severe restrictions on management, such as increased costs and difficulty accessing capital. Auditor independence is crucial, and any deficiency or perceived deficiency will increase agency costs (FIRTH, 1997).

\subsection{Auditor Competence, Reputation and Independence}

To create a demand for audit services, auditors must convince the market that they are competent and independent of the client. Competence implies the probability that the auditor will detect a breach of contract, whereas independence indicates the likelihood of the auditor's reporting that breach (WATTS; ZIMMERMAN, 1983, 1986). In other words, the quality of the audit service is defined as the combined probability of: (a) the auditor's discovering a flaw in the accounting system of his client and (b) his reporting that flaw (DEANGELO, 1981).

According to Watts and Zimmerman (1981), auditors are incentivised to maintain independence, even in the absence of regulation. Thus, independence is considered an important attribute of the external auditor (ANTLE, 1984).

An important aspect related to auditor independence is factual versus apparent independence. Factual independence means that the auditor has an independent mentality when planning and performing an audit, resulting in an impartial audit report. Apparent independence means that the auditor seems to be independent (DOPUCH; KING; SCHWARTZ, 2003). 
In its conceptual framework on auditor independence, NBC PA 290, issued by the Brazilian Federal Accounting Council (Conselho Federal de Contabilidade Brasileiro - CFC), discusses independence of thought (factual) and the appearance of independence. Independence of thought refers to a posture that allows the auditor to present a conclusion free from the influences that compromise his professional judgment, allowing him to act with integrity, objectivity and professional scepticism. The appearance of independence, meanwhile, subjects the auditor to avoiding significant facts and circumstances to the point that a third party would most likely conclude that his integrity, objectivity or professional scepticism has been compromised (CONSELHO FEDERAL DE CONTABILIDADE - CFC, 2012).

Chadegani and Mohamed (2014) revises the literature about how to measure the quality of an auditors' work. Intrinsically unobservable, quality is usually proxied by firm size, reputation, tenure and fess, among other things. With respect to independence, some of the proxies observed include discretionary accruals and/or earnings management (ASHBAUGH; LAFOND; MAYHEW, 2003; CAHAN et al., 2008; JOHNSON; KHURANA; REYNOLDS, 2002), qualified opinions (CRASWELL, 1999), and the probability of issuing a going concern opinion (CAREY; KORTUM; MORONEY, 2012; DHALIWAL et al., 2015; SHARMA; SIDHU, 2001).

\subsection{Non Audit Fees and Other Threats to Independence}

In addition to NASs, this section presents the literature that investigates other sources of threat to independence, including management influence, tenure, switching, and the initial period of contracting.

The incentives that lead an auditor to a loss of independence can be characterised as either direct or indirect. Direct incentives involve actual or potential monetary benefits, for example, economic dependence on the client, whereas indirect incentives arise from circumstances such as the existence of professional or family relationships with members of company management or shareholders (JOHNSTONE; WARFIELD; SUTTON, 2001).

Arguments against the provision of NASs together with financial statement auditing services are expressed in terms of economic dependency and the reciprocity of interests between the auditor and his client. If NASs become sufficiently important to the auditor, either as a whole or in relation to an individual client, this economic dependence can cause bias and a loss of impartiality and objectivity (WINES, 1994). It may even provide a reduction of independence or a perceived lack of independence, with the auditors possibly becoming reluctant to report items that originate from the NASs (FIRTH, 2002).

If the fees for these services are relatively high, then the economic link can increase the likelihood that the auditor will hide "bad news" from shareholders to avoid possible replacement by company management (SIMUNIC, 1984). Craswell, Stokes and Laughton (2002) study the relationship between the dependence on audit fees and the independence of the external auditor. In other words, when formulating their opinions, auditors consider the proportion of fees received from a particular client in relation to their total income; this consideration affects their professional judgment. For that reason, the following research hypothesis can be proposed:

$\mathrm{H}_{1}$ : Independent auditors are less likely to issue a qualified audit report of companies that also receive non-audit services from them.

Empirical studies, however, are not unanimous with regard to any reduction in auditor independence caused by the provision of non-audit services and dependence on fees.

Wines (1994) investigates the potential reduction in audit independence caused by high levels of NASs in the Australian market from 1989-1990. The author found a negative relationship between NASs and qualified opinions, concluding that there is a potential problem of independence when NASs are provided. 
Contrary to the findings of Wines (1994), Craswell (1999), also considering the Australian market but making use of a sample related to the 1984-1987 period and performing a different econometric treatment of the results, was unable to support the hypothesis that NASs threaten auditor independence.

Firth (2002) extends the analysis of the relationship between NASs and the auditor's opinion and concludes that the positive relationship between audit fees and NASs is related to specific events, such as the issuance of new shares, the implementation of a new information or accounting system, reorganisation or restructuring and new CEOs, which require the use of consulting services and longer audit hours. The association between NASs and "clean" reports, according to that author, is associated with a reduction in auditor independence; conversely, it might be that these services help clarify uncertainties and disagreements prior to the audit.

Hay, Knechel and LI (2006) analyse the 1999-2001 period, finding no significant relationship between NASs and the audit report, thus showing no threat to independence.

Another commonly performed analysis is conducted with regard to auditor's reports that poses a threat to the firm's continuity (going concern) and how such a disclosure might be affected by the provision of non-audit services.

Sharma and Sidhu (2001) analyse a sample of 49 bankrupt companies in the Australian market from 1989-1996. Their findings indicate that the provision of NASs reduces the likelihood of the auditor's changing his opinion to report going concern problems.

Focusing on the US market, Defond, Raghunandan and Subramanyam (2002) find no association between the provision of NASs and reduced auditor independence. The authors used a sample of 1,158 firms, of which 96 had a qualified report regarding going concern issues. After several robustness tests, the authors suggested that the institutional incentives of the market itself, such as loss of reputation and litigation costs, outweigh the economic dependency created by higher fees.

The work of Basioudis, Papakonstantinou and Geiger (2008) uses a sample of 58 financially "stressed" companies, of which 29 received a report with a changed opinion regarding the firm's continuity and the rest (control sample) did not. The results, referring to the UK during the 2003 period, suggest that companies that pay more for NASs are less likely to receive a report with a changed opinion regarding going-concern issues. Based on the results of their research, the authors claim that although there is a threat to auditor independence, this threat is not conclusive with regard to a loss of auditor independence because, as Firth (2002) confirms, NASs can be beneficial to the audit process.

The hiring of the audit firm and the negotiation of fees is performed by the company's management. Management's influence in the decision-making process when hiring an auditor may lead to shareholder concerns about the maintenance of auditor independence in safeguarding investors' interests (DHALIWAL et al., 2015). In a country such as Brazil, in which Sternberg, Leal and Bortolon (2011)have found that $65 \%$ of companies have a controller with more than $50 \%$ of the votes, the influence on audit-firm work is expected to be a concern. Controllers' representatives typically influence both executives and the board. In our sample, for example, slightly more than $20 \%$ of the observed board members are independent.

Tenure is another threat to independence that is investigated in the literature. As the result of a long-time relationship with a client, an audit firm will be more confident and less demanding and innovative in audit procedures. In their research on this topic, Johnson, Khurana and Reynolds (2002) arrive at curious results, showing lower financial-report quality for short audit tenures but not for long-standing relationships. However, the authors note that this conclusion should not be extended to environments that involve the mandatory rotation of an audit firm. 
Switching audit firms raises concerns about two sources of threats to audit independence. First, the possible loss of a contract can influence auditors to be more complacent in their reports to a switching client. However, the opposite may also occur, with a qualified report triggering an audit switch. Krishnan; Krishnan and Stephens (1996) find evidence of a two-way causation effect. The second threat that involves switching auditors arises out of the intertemporal fee structure of audit services and how that structure can influence independence. Simon and Francis (1988) find evidence of significant fee reductions in the first year of a contract, with price recovery only after four years. DeAngelo (1981) calls this initial period during which audit firms engage in aggressive price competition as "low balling". Contrary to expectations, (DeAngelo (1981) shows that "low balling" does not impact independence.

In Brazil, mandatory rotation requires the audit firm to be changed every 5 years, and rehiring is only allowed after 3 years. However, Martinez and Reis (2010) analysis finds no evidence of the effect of mandatory rotation on earnings management in Brazilian companies.

The Brazilian environment is also characterised by a possible concentration of auditing. Dantas et al. (2012) work, analysing the 2000-2009 period, suggests that depending on the indicator used to measure market concentration, there is a moderate to high concentration (when using the HHI - Herfindahl-Hirschman Index), but this effect is inconclusive when the C4 is used (the participation rate of the 4 largest audit firms in the examined period).

\section{METHODOLOGY}

Methodological procedures, the database, the development of the independence proxy and the adopted econometric model are presented in the following sections.

\subsection{Data Collection and Processing}

The study population is composed of Brazilian companies listed on BM\&FBovespa from 2010-2012. The data needed for this study were primarily drawn from 3 information sources. Accounting and financial data were obtained using (i) Economatica ${ }^{\circledR}$ software (from Economatica Support to Investors Software LLC, São Paulo, SP, Brazil). This step was followed by the collection of data on corporate governance and NASs and fees, obtained from the (ii) Reference Form (RF). The audit reports were classified into qualified and clean reports to create the proxy for auditor independence (iii). A second proxy identified whether the audit report provided evidence of violation of the company's going concern assumption.

Reference forms (RF) published in 2011-2013 and that contained information related to fiscal years 2010-2012, were studied. The rationale for choosing this period was that during the analysis of the first RFs published in 2010, low-quality information was identified, in addition to the existence of several incomplete reports.

It was decided to use only companies audited by one of the Big 4. This decision meant that a more homogeneous study sample could be created in terms of the quality of services provided and the size of the independent audit firm. The final sample included 154 companies observed over the 3 years and audited by one of the Big 4: PricewaterhouseCoopers, Deloitte Touche Tohmatsu, KPMG or Ernst \& Young.

\subsection{Independence Proxy and Audit Reports}

Measuring auditor independence is not an easy task, given that researchers estimate different metrics or use different proxies to attempt to capture the effect of the external auditor's independence. These metrics may include the issuing of a qualified or adverse opinion or disclaimer opinion and the level of discretionary accruals.

In this research, auditor independence is identified using the auditor's report. A qualified auditor's opinion may indicate independence meaning that the auditor concludes either that the financial statements are materially misstated or that he is unable to obtain sufficient, appropriate

Revista Universo Contábil, ISSN 1809-3337, FURB, Blumenau, v. 12, n. 4, p. 107-128, out./dez., 2016 
evidence to conclude that the financial statements are not free from material misstatement (CONSELHO FEDERAL DE CONTABILIDADE - CFC, 2011).

In Brazil, the audit report has some peculiarities. The decision to issue a qualified opinion and report it to the market certainly demonstrates auditor independence in relation to an auditor's client. However, as a result of previous research, for example, that of Damascena, Paulo and Cavalcante (2011), it was necessary to expand the analysis of the qualified auditor's opinion to include paragraphs of emphasis.

Therefore, the report is considered "qualified" in the following circumstances: when it is unqualified with emphasis or contains a qualified, adverse or disclaimer opinion, as shown below in Table 1:

Table 1 - Change in the Auditor's Opinion

\begin{tabular}{|c|c|c|}
\hline \\
\hline Types of Report & Report & Basis \\
\hline Unqualified opinion & Clean & $\begin{array}{l}\text { NBC TA } 700 \text { - An unchanged opinion is one expressed by the } \\
\text { auditor when he concludes that the financial statements are prepared, } \\
\text { in all material respects, in accordance with the financial reporting } \\
\text { framework (CONSELHO FEDERAL DE CONTABILIDADE - } \\
\text { CFC, 2011). }\end{array}$ \\
\hline $\begin{array}{l}\text { Unqualified opinion with } \\
\text { paragraph(s) of emphasis }\end{array}$ & Qualified & $\begin{array}{l}\text { Several events are presented either as exceptions or as paragraphs of } \\
\text { emphasis, such as: a change in accounting practice, paralysed } \\
\text { operating activities, tax credits, various debts, lawsuits, etc. } \\
\text { (DAMASCENA; PAULO; CAVALCANTE, 2011). }\end{array}$ \\
\hline Qualified opinion & \multirow{3}{*}{ Qualified } & \multirow{3}{*}{$\begin{array}{l}\text { NBC TA } 705 \text { - The auditor must modify the opinion in his report } \\
\text { when he concludes, based on the audit evidence obtained, either that } \\
\text { the financial statements as a whole are materially misstated or that } \\
\text { the auditor is unable to obtain appropriate and sufficient evidence to } \\
\text { conclude that the financial statements as a whole are not free from } \\
\text { material misstatement (CONSELHO FEDERAL DE } \\
\text { CONTABILIDADE - CFC, 2011). }\end{array}$} \\
\hline Adverse opinion & & \\
\hline Disclaimer o & & \\
\hline
\end{tabular}

It is noteworthy that in the case of paragraphs of emphasis, divergence from accounting practice due to the valuation of investments in subsidiaries and affiliates was disregarded. This procedure was necessary due to the large number of "qualified reports" that would be involved but that would not necessarily represent relevant data, such as the changes that occurred because of the methodology that Brazil adopted when it adopted international accounting standards. Table 2 below illustrates the emphases that were considered (or not considered) to represent a qualified auditor's opinion.

Table 2 - Examples of Emphases in the Audit Reports

\begin{tabular}{l|l}
\hline \multicolumn{1}{c}{$\begin{array}{c}\text { Emphases Considered to be a Change in the } \\
\text { Auditor's Opinion }\end{array}$} & $\begin{array}{l}\text { Emphases Not Considered to be a Change in the } \\
\text { Auditor's Opinion }\end{array}$ \\
\hline - A substantial part of, or all transactions, is/are & $\begin{array}{l}\text { - Divergence in the accounting policy due to the } \\
\text { conducted with a related party, which can generate } \\
\text { valuation of investments in subsidiaries, affiliates } \\
\text { and controlled companies. Together, they should } \\
\text { a high degree of dependence; }\end{array}$ \\
$\begin{array}{l}\text { - Uncertainty of receipt of the client's accounts } \\
\text { receivable; }\end{array}$ & $\begin{array}{l}\text { IFRS purposes, the cost or fair value should be } \\
\text { - Absence in the financial statements of provisions }\end{array}$ \\
$\begin{array}{l}\text { for loss of assets or adjustments due to } \\
\text { uncertainties. }\end{array}$ & $\begin{array}{l}\text { Restatement of previously issued opinion } \\
\text { attributable to the restatement of financial } \\
\text { statements, provided the auditor agrees with the } \\
\text { reclassifications made in the restatement; }\end{array}$ \\
& - Absence of audit in the Social Report. \\
\hline
\end{tabular}


Given the difficulty of identifying the auditors' independence that this research used as a second measure, as in Carey, Kortum and Moroney (2012), the issuance of a going concern modified audit opinions.

\subsection{Econometric Model}

The effect of contracting NASs on the likelihood of the auditor issuing a qualified report is analysed using the following logit regression model:

$$
\begin{aligned}
& (\text { OPINION;GOING CONCERN })=\alpha_{i}+\beta_{1} N A S_{i t}+\beta_{2} \text { NAS/AUDFEE } E_{i t}+\beta_{3} A U D F E E+ \\
& N A S_{i t}+\beta_{4} \text { INITIAL }_{i t}+\beta_{5} \text { TENURE }_{i t}+\beta_{6} \text { REHIRED }_{i t}+\beta_{7} \text { RIGHTSMIS }_{i t}+\beta_{8} N M 2_{i t}+ \\
& \beta_{9} E X T_{i t}+\beta_{10} C E O_{i t}+\beta_{11} A U D C M T_{i t}+\beta_{12} \text { SIZE }_{i t}+\beta_{13} D E B T_{i t}+\beta_{14} I_{N V E N T O R Y_{i t}}+ \\
& \beta_{15} R_{E C E I V A B L E S}+\beta_{16} \text {RETURN }_{i t}+\beta_{17} L O S S_{i t}+\beta_{18} A G E_{i t}+\beta_{19} D E L A Y_{i t}+\varepsilon_{i t}
\end{aligned}
$$

where:

OPINION = dummy, takes the value of 1 if the audit report contains some change, otherwise 0

GOING CONCERN = dummy, takes the value of 1 if the audit report contains some change related to a violation of the going concern assumption (Going Concern Opinion), otherwise 0

$N A S$ = natural logarithm of the value of non-audit service fees

NAS/AUDFEE = ratio of the amount paid for non-audit services to the amounts paid for an audit of the financial statements

$A U D F E E+N A S=$ natural logarithm of the sum of the audit and non-audit service fees

INITIAL = dummy, takes the value of 1 if the audit engagement is in either the first or second year

TENURE = measured as the number of continuous years of auditor employment since 2004

REHIRED dummy, takes the value of 1 if the audit firm was rehired after the three year minimum cooling-off period

RIGHTSMIS = rights mismatch, calculated using the ratio of the percentage of shares with voting rights and the total percentage of shares, both of the largest shareholder

NM2 =dummy, takes the value of 1 if the company is listed on the Novo Mercado or Level 2 of BM\&FBovespa (segments with more demanding rules for corporate governance)

$E X T=$ independent board members, calculated based on the percentage of independent board members

$C E O=d u m m y$, takes the value of 1 if the president of the board of directors and the CEO are different people

AUDCMT = dummy, takes the value of 1 if the firm has an audit committee

SIZE = calculated according to the natural logarithm of total assets

$D E B T$ = evaluated as the ratio of the short-term and long-term debt to total assets

INVENTORY = ratio of inventory to total assets

RECEIVABLES = ratio of receivables to total assets

RETURN = firms' return on 31/03/XX, calculated using the following formula: $\operatorname{RET}=\operatorname{Ln}\left(P_{t+1} / P_{t}\right)$

$L O S S=d u m m y$, equal to 1 if loss is reported in the year

$A G E=$ logarithm of the number of years listed on the stock exchange 
DELAY = number of days between the end of the financial year and the issuance of the audit report

The largest companies (SIZE) tend to have a lower likelihood of default because they have more resources to renegotiate financial commitments. Therefore, it is less likely that their audit report will be qualified (DEFOND; RAGHUNANDAN; SUBRAMANYAM, 2002; REYNOLDS; FRANCIS, 2000). Companies with high levels of debt (DEBT) may experience difficulty meeting their commitments and obtaining new financing, which would increase the risk of financial stress and the likelihood of qualifications to the audit report (DEFOND; RAGHUNANDAN; SUBRAMANYAM, 2002). Debt further increases both agency costs and company risk, requiring more effort from the auditor because of a higher audit risk (FIRTH, 2002).

It is noteworthy that both INVENTORY and RECEIVABLES are assets that are more difficult to audit and require more effort, consequently creating an increased audit risk. Therefore, these assets are more strongly associated with audit errors, leading to increased litigation (FIRTH, 2002; HAY; KNECHEL; LI, 2006).

Companies with lower RETURNS are more likely experience financial difficulties and therefore are more likely to receive qualifications from their auditors (DEFOND; RAGHUNANDAN; SUBRAMANYAM, 2002). In short, the DEBT, INVENTORY, RECEIVABLES, RETURN and LOSS variables are proxies for various risk factors, and therefore, a significant relationship is expected with the propensity for audit reports to be changed.

Companies that have been on the market longer (AGE) would have reduced likelihood of going into default, given that they are better known by, and less involved in litigation with, investors, which negatively affects the probability of a qualified auditor's report (DEFOND; RAGHUNANDAN; SUBRAMANYAM, 2002; FIRTH, 2002).

The auditor needs time (DELAY) to address problems that require a more thorough examination. Those problems generally include discussions with managers and can involve many aspects, including breach of covenants, earnings management, fraud, etc. However, auditors are pressured by managers to reduce audit time, which can often lead to the auditor agreeing with management (SHARMA; SIDHU, 2001). Moreover, Mutchler, Hopwood and Mckeown (1997) show that large audit firms are more likely to issue qualified opinions.

Given the importance of management in the client-auditor relationship Dhaliwal et al. (2015) and the relevance of this subject in a scenario such as that of Brazil, which is characterised by ownership and control concentration, it is important to control for some corporate governance characteristics that can minimise these effects. For that reason, RIGHTSMIS (rights mismatch), NM2 (different levels of corporate governance), EXT (independent members of the board), CEO (chairman of the board of directors and CEO being different people) and AUDCMT (audit committee) were included. Except for RIGHTSMIS, the other variables are proxies for good corporate governance practices and might signal less influence of management and controlling shareholders over the independent auditor. Additionally, based on the premise established by Griffin, Lont and Sun (2008), good governance practices reduce audit risk. Therefore, for those representing good practices (NM2, EXT, CEO and AUDCMT), a positive relationship is expected with auditor independence, whereas a negative relationship is expected between auditor independence and RIGHTSMIS.

The existence of a long-standing relationship is another potential threat to auditor independence that has been studied in the literature (JOHNSON; KHURANA; REYNOLDS, 2002). To control for this potential influence, we add the variable TENURE, which measures the number of years of auditor employment. Therefore, the expected sign is negative. 
In a country such as Brazil, where regulations require mandatory rotation of audit firms every five years, long-term relationships are not expected. However, rehiring is allowed after a three-year cooling-off period. Rehiring may represent a strong connection between the audit firm and the company, and this relationship might represent a threat to independence. Therefore, the model controls for this possibility through REHIRED and the expected sign is negative.

The extant literature shows that audit fees have an intertemporal structure, with the initial years of hiring representing a "low balling" period (DEANGELO, 1981; SIMON; FRANCIS, 1988). The price decrease in the initial years (which is intended to attract the client) can also represent a threat to independence. Contrary to expectations, De Angelo (1981) shows that "low balling" does not have an impact on independence. REHIRED identifies this type of event in the sample.

\section{ANALYSIS OF RESULTS}

The results of the descriptive analysis, the econometric models and the adopted robustness tests are presented below.

\subsection{Descriptive Statistics}

The figures for the descriptive statistics regarding variables of a continuous nature, such as means and standard deviations, and mean qualitative data (binary) are shown in Table 3.

On average, companies in the sample have a DEBT of $57.6 \%$, ranging between $6.2 \%$ and $144 \%$, in relation to total assets. The mean time between financial year end $31 / 12$ and the date of issue of the audit report is 68 days.

Table 3 - Descriptive Statistics of Variables

\begin{tabular}{|c|c|c|c|c|c|}
\hline $\begin{array}{c}\text { Quantitative } \\
\text { Variables }\end{array}$ & Observations & Mean & $\begin{array}{l}\text { Standard } \\
\text { Deviation }\end{array}$ & Minimum & Maximum \\
\hline$\overline{A G E}$ & 437 & 0.958 & 0.364 & 0.000 & 1.415 \\
\hline AUDFEE/ASSET & 437 & 0.316 & 0.357 & 0.001 & 2.375 \\
\hline$A U D F E E+N A S$ & 437 & 13.459 & 1.203 & 9.602 & 16.994 \\
\hline$D E B T$ & 437 & 0.576 & 0.214 & 0.062 & 1.444 \\
\hline$D E L A Y$ & 437 & 68.009 & 19.497 & 23.000 & 151.000 \\
\hline$E X T$ & 437 & 0.228 & 0.209 & 0.000 & 0.889 \\
\hline INVENTORY & 437 & 0.089 & 0.093 & 0.000 & 0.344 \\
\hline$N A S$ & 437 & 5.761 & 6.171 & 0.000 & 15.133 \\
\hline NAS/AUDFEE & 437 & 0.290 & 1.609 & 0.000 & 32.095 \\
\hline RECEIVABLES & 437 & 0.151 & 0.113 & 0.000 & 0.475 \\
\hline RETURN & 437 & 0.023 & 0.382 & -1.361 & 0.820 \\
\hline RIGHTSMIS & 437 & 1.180 & 0.371 & 0.743 & 3.000 \\
\hline SIZE & 437 & 15.008 & 1.498 & 10.823 & 19.304 \\
\hline TENURE & 437 & 3.382 & 2.194 & 1 & 8 \\
\hline \multicolumn{2}{|c|}{ Qualitative Variables } & Mean (\%) & \multicolumn{2}{|c|}{ Qualitative Variables } & Mean (\%) \\
\hline \multirow{4}{*}{\multicolumn{2}{|c|}{$\begin{array}{l}\text { AUDCMT } \\
\text { CEO } \\
\text { GOING CONCERN } \\
\text { INITIAL }\end{array}$}} & 35.24 & \multirow{4}{*}{\multicolumn{2}{|c|}{$\begin{array}{l}\text { LOSS } \\
\text { NM2 } \\
\text { OPINION } \\
\text { REHIRED }\end{array}$}} & 18.31 \\
\hline & & 84.67 & & & 58.12 \\
\hline & & 10.07 & & & 16.48 \\
\hline & & 38.67 & & & 3.43 \\
\hline
\end{tabular}

Obs.: All continuous variables were Winsorised at $1 \%$ and $99 \%$.

The mean RETURN of the companies was $2.3 \%$, and $18 \%$ of the sampled companies showed a LOSS.

In analysing the AGE variable, the final sample of this study includes companies considered "newcomers" on the BM\&FBovespa and companies that have been listed for a long period of time, i.e., companies that are well known by investors in the Brazilian capital market.

With regard to corporate governance aspects, it is noteworthy that $58 \%$ of the companies are listed on the Novo Mercado or Level 2 (NM2) and 35\% of companies have an audit 
committee (AUDCMT). In addition, it can be observed that in approximately $85 \%$ of these companies, the chairman and CEO are different people and only $22.8 \%$ of board members are independent. Finally, $16 \%$ of the companies received a qualified audit report (OPINION) in 1 or more of the surveyed years, and $10 \%$ of the companies received an audit report that was qualified because of a violation of the going concern assumption (GOING CONCERN).

The average employment time in the sample is 3.4 years (TENURE), and $38 \%$ of audit firms are in the first or second year of their contract (INITIAL). These data indicates that longterm relationships may not be a concern. In the sample, $34 \%$ of audit firms were rehired after the cooling-off period (REHIRED).

Table 4 shows the number of companies present in the sample by sector and the mean values of the audit fees and NAS fees in US\$ for 2010-2012.

Table 4 - Mean Values of Spending on Audit Fees and Non-audit Services, by Sector

\begin{tabular}{|c|c|c|c|c|c|c|c|}
\hline \multirow{2}{*}{ Sector } & \multirow{2}{*}{ Companies } & \multicolumn{3}{|c|}{ Audit Fees (US\$) } & \multicolumn{3}{|c|}{ Non-audit Services (US\$) } \\
\hline & & 2010 & 2011 & 2012 & 2010 & 2011 & 2012 \\
\hline Agro and Fishery & 1 & 322,792 & 109,725 & 123,905 & 196,198 & 417,290 & 55,989 \\
\hline Food and Drink & 7 & 952,659 & $1,810,616$ & $1,346,593$ & 459,623 & 572,198 & 367,173 \\
\hline Trade & 11 & 535,128 & 724,171 & 561,995 & 245,454 & 201,331 & 299,882 \\
\hline Construction & 15 & 459,106 & 463,921 & 475,557 & 86,255 & 58,354 & 48,815 \\
\hline Electronics & 5 & 546,762 & 404,481 & 384,494 & 104,417 & 24,066 & 21,673 \\
\hline Electricity & 18 & 442,103 & 446,208 & 280,258 & 129,967 & 143,850 & 322,380 \\
\hline Industrial Machinery & 4 & 309,633 & 370,715 & 337,390 & 228,525 & 105,354 & 51,323 \\
\hline Mining & 4 & $3,523,543$ & $3,412,008$ & $2,900,980$ & 215,889 & 223,137 & 291,139 \\
\hline Non-metallic Minerals & 1 & 385,839 & 534,257 & 99,929 & - & - & - \\
\hline Others & 30 & 369,272 & 462,838 & 348,204 & 363,353 & 351,981 & 232,356 \\
\hline Pulp and Paper & 3 & $1,119,807$ & 901,112 & 992,643 & 801,290 & 113,749 & 125,109 \\
\hline Oil and Gas & 2 & 221,966 & 237,767 & 208,195 & 9,667 & 63,082 & 174,005 \\
\hline Chemicals & 8 & 689,385 & 869,688 & 803,323 & 900,764 & 57,751 & 321,328 \\
\hline Steel and Metallurgy & 13 & $1,236,539$ & $1,462,863$ & $1,358,344$ & 264,953 & 144,790 & 230,240 \\
\hline Software and Data & 2 & 480,123 & 481,909 & 392,705 & 206,854 & 257,822 & 148,140 \\
\hline Telecommunications & 4 & $1,826,597$ & $2,554,462$ & 997,881 & 46,343 & 235,590 & 346,911 \\
\hline Textiles & 8 & 190,553 & 217,218 & 135,999 & 100,180 & 160,707 & 104,636 \\
\hline Transport Services & 10 & 678,093 & 824,941 & 780,966 & 85,553 & 204,771 & 190,477 \\
\hline Vehicles and Parts & 8 & 601,818 & 820,029 & 738,049 & 92,962 & 573,411 & 123,383 \\
\hline Overall mean & 154 & 675,537 & 806,466 & 651,885 & 238,179 & 239,544 & 213,392 \\
\hline
\end{tabular}

Obs.: Data regarding information on the amount paid to the auditing firm for the provision of auditing of the financial statements and non-audit services were extracted from Reference Forms of 154 Brazilian companies listed on BM\&FBovespa in the years 2010 to 2012. Values in R\$ (Reais) were converted to US\$ (dollars) using the average annual exchange rate. The classification of sectors was performed using Economatica® software.

With regard to NASs, especially with regard to 2010, the "Pulp and Paper" sector, which contained only 3 companies, paid an average of US\$ 0.35 million. The "Chemicals" sector spent an average of US\$ 0.43 million on NASs, with 8 companies in the sample belonging to this sector. On average, during this period, the cost of NASs represented $32 \%$ of the amount paid for the audit service.

\subsection{Propensity to Change the Audit Report}

Table 5 shows the results for the models with the dependent variable being the presence of a qualified opinion (models 1 to 3 ) and the auditor's opinion on the firm's continuity (models 4 to 6). This type of approach has been adopted in studies conducted in countries with capital markets considered to be more developed (BASIOUDIS; PAPAKONSTANTINOU; GEIGER, 2008; DEFOND; RAGHUNANDAN; SUBRAMANYAM, 2002; SHARMA; SIDHU, 2001). To date, it is known that there is insufficient evidence from empirical studies conducted in Brazil. 
Table 5 - Propensity to Change an Audit Report

\begin{tabular}{|c|c|c|c|c|c|c|c|c|c|c|c|c|c|}
\hline \multicolumn{14}{|c|}{$\begin{array}{c}(\text { OPINION;GOING CONCERN })=\alpha_{i}+\beta_{1} N A S_{i t}+\beta_{2} N A S / A U D F E E_{i t}+\beta_{3} A U D F E E+N A S_{i t}+\beta_{4} S_{I Z E_{i t}}+\beta_{5} D_{E B T_{i t}}+\beta_{6} I N V E N T O R Y_{i t}+\beta_{7} R E C E I V A B L E S_{i t}+\beta_{8} R E T U R N_{i t}+ \\
\beta_{9} \text { LOSS }_{i t}+\beta_{10} A G E_{i t}+\beta_{11} D E L A Y_{i t}+\beta_{12} R I G H T S M I S_{i t}+\beta_{13} N M 2_{i t}+\beta_{14} E X T_{i t}+\beta_{15} C E O_{i t}+\beta_{16} A U D C M T_{i t}+\beta_{17} I N I T I A L_{i t}+\beta_{18} T E R N U R E_{i t}+\beta_{19} R E H I R E D_{i t}+\varepsilon_{i t}\end{array}$} \\
\hline \multirow{3}{*}{$\begin{array}{c}\text { Explanatory } \\
\text { Variables }\end{array}$} & \multirow{3}{*}{$\begin{array}{l}\text { Predicted } \\
\text { sign }\end{array}$} & \multicolumn{6}{|c|}{ Dependent Variable: OPINION } & \multicolumn{6}{|c|}{ Dependent Variable: GOING CONCERN } \\
\hline & & \multicolumn{2}{|c|}{ (1) } & \multicolumn{2}{|c|}{$(2)$} & \multicolumn{2}{|c|}{ (3) } & \multicolumn{2}{|c|}{$(4)$} & \multicolumn{2}{|c|}{$(5)$} & \multicolumn{2}{|c|}{ (6) } \\
\hline & & Coefficient & $t$-Stat & Coefficient & $t$-Stat & Coefficient & $t$-Stat & Coefficient & $t$-Stat & Coefficient & t-Stat & Coefficient & $t$-Stat \\
\hline$\overline{N A S}$ & - & -0.0323 & $(-1.212)$ & & & & & -0.0304 & $(-0.904)$ & & & & \\
\hline NAS/AUDFEE & - & & & -0.199 & $(-0.716)$ & & & & & -0.108 & $(-0.884)$ & & \\
\hline$A U D F E E+N A S$ & - & & & & & $-0.403 *$ & $(-2.036)$ & & & & & $-0.523 * *$ & $(-2.586)$ \\
\hline INITIAL & & -0.439 & $(-0.979)$ & -0.370 & $(-0.817)$ & -0.543 & $(-1.215)$ & -0.980 & $(-1.517)$ & -0.908 & $(-1.373)$ & -1.111 & $(-1.851)$ \\
\hline TENURE & & -0.106 & $(-1.071)$ & -0.0986 & $(-0.974)$ & -0.115 & $(-1.142)$ & -0.232 & $(-1.426)$ & -0.227 & $(-1.357)$ & -0.247 & $(-1.617)$ \\
\hline REHIRED & & 0.748 & $(1.004)$ & 0.754 & (1.015) & 0.806 & (1.042) & 0.466 & (0.399) & 0.470 & $(0.409)$ & 0.516 & $(0.407)$ \\
\hline RIGHTMIS & - & -0.464 & $(-1.002)$ & -0.437 & $(-0.934)$ & -0.542 & $(-1.211)$ & 0.213 & $(0.373)$ & 0.254 & $(0.448)$ & 0.147 & $(0.273)$ \\
\hline$N M$ & + & 0.00426 & $(0.0089)$ & 0.00347 & $(0.0073)$ & 0.134 & $(0.273)$ & -0.518 & $(-0.943)$ & -0.551 & $(-1.014)$ & -0.283 & $(-0.509)$ \\
\hline$E X T$ & + & $2.189 *$ & $(2.178)$ & $2.212 *$ & $(2.223)$ & $2.226^{*}$ & $(2.162)$ & 0.431 & $(0.385)$ & 0.521 & $(0.464)$ & 0.328 & $(0.296)$ \\
\hline CEO & + & $-1.208 * *$ & $(-2.793)$ & $-1.212 * *$ & $(-2.775)$ & $-1.219 * *$ & $(-2.823)$ & -0.712 & $(-1.149)$ & -0.730 & $(-1.159)$ & -0.697 & $(-1.182)$ \\
\hline$A U D C M T$ & + & 0.120 & $(0.366)$ & 0.0384 & (0.114) & 0.199 & $(0.548)$ & -0.0953 & $(-0.209)$ & -0.203 & $(-0.450)$ & 0.0742 & $(0.151)$ \\
\hline SIZE & - & -0.0882 & $(-0.710)$ & -0.120 & $(-0.960)$ & 0.0274 & $(0.203)$ & 0.122 & $(0.855)$ & 0.102 & $(0.710)$ & 0.271 & (1.806) \\
\hline$D E B T$ & + & $2.288 * *$ & $(2.699)$ & $2.308 * *$ & $(2.675)$ & $2.437 * *$ & $(2.792)$ & $3.034 *$ & $(2.331)$ & $3.068 *$ & $(2.278)$ & $3.327 *$ & $(2.409)$ \\
\hline INVENTORY & + & $-6.624 *$ & $(-2.192)$ & $-7.035^{*}$ & $(-2.323)$ & -5.326 & $(-1.747)$ & $-11.56 * *$ & $(-2.882)$ & $-12.12 * *$ & $(-3.036)$ & $-8.483^{*}$ & $(-2.195)$ \\
\hline RECEIVABLES & + & $-4.897 *$ & $(-2.426)$ & $-4.627 *$ & $(-2.338)$ & $-5.397 * *$ & $(-2.603)$ & -2.242 & $(-0.987)$ & -1.870 & $(-0.853)$ & -3.206 & $(-1.359)$ \\
\hline RETURN & - & -0.570 & $(-1.239)$ & -0.541 & $(-1.160)$ & -0.485 & $(-1.064)$ & -0.868 & $(-1.541)$ & -0.790 & $(-1.413)$ & -0.687 & $(-1.287)$ \\
\hline LOSS & + & $1.036^{*}$ & $(2.550)$ & $1.040 *$ & $(2.538)$ & $1.151 * *$ & $(2.778)$ & $1.226^{*}$ & $(2.482)$ & $1.241 *$ & $(2.459)$ & $1.397 * *$ & $(2.839)$ \\
\hline$A G E$ & - & 0.550 & $(0.987)$ & 0.569 & $(0.991)$ & 0.543 & $(0.981)$ & -1.336 & $(-1.761)$ & -1.339 & $(-1.713)$ & -1.437 & $(-1.851)$ \\
\hline DELAY & + & $0.0266 * *$ & $(3.618)$ & $0.0281 * *$ & $(3.935)$ & $0.0260 * *$ & $(3.631)$ & $0.0401 * *$ & (4.099) & $0.0412 * *$ & $(4.215)$ & $0.0381 * *$ & $(3.657)$ \\
\hline CONSTANT & $+/-$ & -1.649 & $(-0.760)$ & -1.500 & $(-0.679)$ & 1.770 & $(0.590)$ & $-5.391 *$ & $(-2.331)$ & $-5.364 *$ & $(-2.297)$ & -0.922 & $(-0.305)$ \\
\hline Observations & & 43 & & 43 & & 43 & & 43 & & 43 & & 437 & \\
\hline Pseudo R-sq & & 0.2 & & 0.2 & & 0.2 & & 0.36 & & 0.36 & & 0.38 & \\
\hline
\end{tabular}

Obs.: **** were significant at $1 \%$ and $5 \%$ respectively. All of the continuous variables were Winsorised at $1 \%$ and $99 \%$. White robust standard errors, corrected for heteroscedasticity. 
The coefficients of the variables of interest, (NAS) and (NAS/AUDFEE), had a negative sign; however, this result was not statistically significant. This evidence indicates that the provision of non-audit services did not necessarily result in a greater likelihood of a qualified audit report or a report with going concern statement being issued. In other words, there is no evidence of reduced auditor independence caused by the provision of NASs in the sample. Our results are in line with Craswell (1999); Defond, Raghunandan and Subramanyam (2002) and Hay, Knechel and Li (2006).

The provision of NASs in conjunction with an audit may lead to reduced auditor independence attributable to the possible dependence of the auditor's firm on his client or the possibility of the auditor's avoiding changing the report based on a procedure arising out of his consultancy. However, Firth (2002) argues that NASs can actually help the client solve problems. Such problems may be related to the accounting system, inefficient information and management, fraud detection, high debt levels and low liquidity levels. Moreover, as Defond, Raghunandan and Subramanyam (2002) note, institutional incentives related to the costs of a possible loss of reputation are sufficient to maintain auditors' independence even when providing services other than auditing.

However, when the fees for NASs are summed with audit fees, both approaches, with OPINION and GOING CONCERN as dependent variables (models 3 and 6), show a negative and statistically significant impact on independence. This result may signal that it is not the type of service (audit or non-audit), but the total fees and the possible resulting economic dependence on the client that compromises independence.Cahan et al. (2008) investigate the impact of NASs on independence using discretionary accruals as a proxy. Their results also do not show a significant relationship between NASs and compromising independence. However, they also find significant results for a specific subset in which NASs interacts with client importance. The positive relation between NASs and discretionary accruals arises when the economic bond comes from NASs and the client is more important (in terms of the revenues from that client).

The models tested have controls for other threats to independence. Despite their negative sign, a long-term relationship (TENURE) and being in the first two years of contract (INITIAL) do not show statistical significance and do not impact independence. Being rehired after the cooling-off period (REHIRED), which could represent a strong connection to a client, does not impact independence.

Management's influence in hiring and monitoring auditor work raises concerns about compromised audit independence (DHALIWAL et al., 2015). In a country such as Brazil, which is characterised by ownership and control concentration and boards with few independent members, this is a special concern that could be minimised by good corporate governance practices.

The presence of independent board members (EXT) increases the auditor's propensity to issue a qualified report. This result may be related to increased monitoring by independent board members. In contrast, when the chairman of the board of directors and the CEO are different individuals (CEO), as recommended in terms of best corporate governance practice, the likelihood of issuing a qualified report is reduced. This result, which in principle is contrary to expectations, may be attributable to Brazil's specific characteristics. Brazil's high ownership concentration can be reflected in the occupation of these positions by representatives of controllers or families that can affect the relationship between the company and its auditors. Further data and analysis are required to research this possibility.

That said, the results for EXT and CEO are not maintained in the models with GOING CONCERN as the dependent variable. 
Table 6 - Propensity to Change an Audit Report (Sample of Qualifiable Companies)

$($ OPINION;GOING CONCERN $)=\alpha_{i}+\beta_{1} N A S_{i t}+\beta_{2} N A S / A U D F E E_{i t}+\beta_{3} A U D F E E+N A S_{i t}+\beta_{4} S I Z E_{i t}+\beta_{5} D E B T_{i t}+\beta_{6} I N V E N T O R Y_{i t}+\beta_{7} R E C E I V A B L E S_{i t}+\beta_{8} R E T U R N_{i t}+$

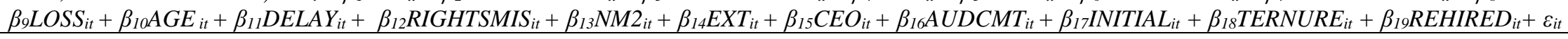

\begin{tabular}{|c|c|c|c|c|c|c|c|c|c|c|c|c|}
\hline \multirow{3}{*}{$\begin{array}{c}\text { Explanatory } \\
\text { Variables }\end{array}$} & \multicolumn{6}{|c|}{ Dependent Variable: OPINION } & \multicolumn{6}{|c|}{ Dependent Variable: GOING CONCERN } \\
\hline & \multicolumn{2}{|c|}{ (1) } & \multicolumn{2}{|c|}{ (2) } & \multicolumn{2}{|c|}{ (3) } & \multicolumn{2}{|c|}{ (4) } & \multicolumn{2}{|c|}{ (5) } & \multicolumn{2}{|c|}{ (6) } \\
\hline & Coefficient & $t$-Stat & Coefficient & t-Stat & Coefficient & t-Stat & Coefficient & $t$-Stat & Coefficient & $t$-Stat & Coefficient & $t$-Stat \\
\hline$N A S$ & -0.0375 & $(-0.374)$ & & & & & -0.0691 & $(-0.739)$ & & & & \\
\hline NAS_AUDFEE & & & 2.409 & $(0.847)$ & & & & & 3.400 & $(1.234)$ & & \\
\hline$A U D F E E+N A S$ & & & & & -1.385 & $(-1.674)$ & & & & & $-4.206^{*}$ & $(-2.253)$ \\
\hline INITIAL & 1.345 & $(0.824)$ & 1.615 & $(1.157)$ & 0.781 & $(0.322)$ & 3.959 & $(1.408)$ & 4.605 & $(1.767)$ & 3.870 & $(1.175)$ \\
\hline TENURE & 0.444 & $(1.384)$ & 0.710 & $(1.390)$ & 0.489 & $(0.995)$ & 1.889 & (1.853) & $2.179 *$ & $(2.415)$ & $2.839 * *$ & $(2.755)$ \\
\hline REHIRED ${ }^{(I)}$ & 2.006 & (1.199) & 2.215 & (1.384) & 1.967 & (1.166) & - & & - & & - & \\
\hline RIGHTMIS & 0.409 & $(0.228)$ & -0.112 & $(-0.0576)$ & 0.580 & $(0.345)$ & 1.444 & $(0.672)$ & 0.364 & $(0.119)$ & -0.121 & $(-0.0317)$ \\
\hline$N M$ & -0.739 & $(-0.478)$ & -0.572 & $(-0.300)$ & -0.587 & $(-0.395)$ & -1.636 & $(-0.886)$ & -1.365 & $(-0.562)$ & 0.498 & $(0.243)$ \\
\hline$E X T$ & 4.011 & $(0.783)$ & 4.267 & $(0.973)$ & 3.583 & $(0.665)$ & -1.918 & $(-0.451)$ & 1.272 & $(0.423)$ & -3.743 & $(-0.930)$ \\
\hline CEO & -0.408 & $(-0.315)$ & -0.619 & $(-0.389)$ & -0.803 & $(-0.586)$ & 0.550 & $(0.400)$ & 0.145 & $(0.102)$ & 1.068 & $(0.590)$ \\
\hline AUDCMT & -0.814 & $(-0.574)$ & -1.009 & $(-0.565)$ & -1.107 & $(-0.554)$ & -2.253 & $(-1.355)$ & -2.639 & $(-1.639)$ & -4.410 & $(-1.906)$ \\
\hline SIZE & -0.227 & $(-0.324)$ & -0.234 & $(-0.311)$ & 0.937 & $(0.674)$ & 1.089 & $(1.287)$ & 0.863 & $(1.417)$ & $5.121 *$ & $(2.394)$ \\
\hline$D E B T$ & 4.201 & $(0.693)$ & 2.953 & $(0.579)$ & 6.517 & $(1.131)$ & $6.404 *$ & $(2.364)$ & 6.105 & (1.609) & $20.65^{*}$ & $(2.018)$ \\
\hline INVENTORY & -1.355 & $(-0.144)$ & -4.415 & $(-0.457)$ & -2.746 & $(-0.290)$ & -1.773 & $(-0.155)$ & -7.560 & $(-0.675)$ & -13.46 & $(-1.039)$ \\
\hline RECEIVABLES & -5.839 & $(-0.502)$ & -3.566 & $(-0.334)$ & -4.451 & $(-0.371)$ & -6.493 & $(-0.652)$ & -1.466 & $(-0.189)$ & -2.345 & $(-0.217)$ \\
\hline RETURN & -0.248 & $(-0.257)$ & -0.286 & $(-0.288)$ & -0.351 & $(-0.356)$ & -4.189 & $(-1.477)$ & -3.025 & $(-1.674)$ & $-5.846 * *$ & $(-2.719)$ \\
\hline$A G E$ & -1.343 & $(-0.716)$ & -0.0941 & $(-0.0359)$ & -1.039 & $(-0.517)$ & -7.601 & $(-1.323)$ & -4.700 & $(-0.863)$ & -5.877 & $(-1.296)$ \\
\hline DELAY & 0.0249 & $(1.188)$ & 0.0132 & $(0.747)$ & 0.0140 & $(0.799)$ & 0.0358 & $(1.693)$ & 0.0206 & $(1.001)$ & 0.0314 & $(0.821)$ \\
\hline CONSTANT & -3.082 & $(-0.353)$ & -2.648 & $(-0.269)$ & -2.376 & $(-0.235)$ & $-26.34 *$ & $(-2.541)$ & $-24.55 * *$ & $(-2.625)$ & $-42.71 *$ & $(-2.417)$ \\
\hline Observations & 46 & & 46 & & 46 & & 44 & & 44 & & 44 & \\
\hline Pseudo R-sq & 0.255 & & 0.275 & & 0.287 & & 0.493 & & 0.514 & & 0.593 & \\
\hline
\end{tabular}

Obs.: (1) REHIRED was dropped in models 4 to 6 because of collinearity with GOING CONCER
were Winsorised at $1 \%$ and $99 \%$. White robust standard errors, corrected for heteroscedasticity. 
The time between the end of the financial year and the issuing of the audit report (DELAY) also helped increase the probability of either a qualified report or a report with a going concern opinion. As Sharma and Sidhu (2001) find, longer periods may be related to greater efforts being made by the auditor to alert management to problems related to breach of covenants, accounting practices not in accordance with prevailing accounting standards and even fraud. Contrary to expectations, the SIZE variable had a positive sign; however, it had no statistical significance.

The results also indicate that companies with higher levels of RECEIVABLES and INVENTORY have a lower propensity to receive a qualified opinion, although receivables are assets that require a greater auditing effort because of the difficulties involved in auditing them (FIRTH, 2002).

The robustness test involved the definition of a specific segment of the sample. The sample was divided into companies considered qualifiable, i.e., more indebted companies (DEBT) and those with the disclosure of loss (LOSS). It was assumed that these characteristics increase the likelihood that the auditor will issue a qualified audit report. Given this premise, a new analysis was performed using only those companies considered qualifiable, i.e., those with a high level of debt or disclosing loss. The purpose of this sample section is to determine, for the companies considered qualifiable, whether contracting NASs reduces auditor independence.

The observations were first classified in order of increasing debt and divided into quartiles, with the sample taken comprising the $25 \%$ of companies that were the most indebted. Finally, companies that presented a loss (LOSS) were retained in the subsample and the rest excluded.

The subsample of qualifiable companies had 46 observations, of which $18(39.13 \%)$ companies received a qualified audit report and 14 companies $(30.43 \%)$ received a report with statements about the firm's continuity. The logit regression results are shown in Table 6.

The results are similar to the broad sample. The only version of NASs that showed statistical significance was the one in which the values of fees are summed to audit services. The evidence in favour of economic dependence (more than NAS specifically) compromising independence is repeated. Unlike previous results and the expected sign, TENURE showed a positive and significant relationship with the probability of receiving a going concern opinion.

The small sample in this analysis raises concerns about the validity of the conclusions. These results suggest, moreover, that threats to independence should be investigated in specific situations more than in general situations.

\section{FINAL CONSIDERATIONS}

This study aimed at evaluating whether the provision of NASs together with the audit of financial statements reduces the independence of the external auditors of Brazilian companies traded on BM\&FBovespa.

For public companies, although there is a legal obligation, it is necessary to ensure auditors' independence from their clients because, if this independence is violated, in addition to the loss of the audit firm's reputation, the companies involved may incur increased agency costs. Auditor independence is understood to mean the probability of issuing an audit report that informs the market of the existence of accounting information that is either low quality or in violation of accounting practices. However, it is first necessary for the auditor to be competent to identify this failure.

One of the great debates, both in academia and among regulators concerns whether auditor independence is reduced when auditors are hired by their clients to provide NASs. This reduction in independence may occur because of the economic importance that these services can assume, whether as a whole or with regard to a particular client. Another argument is that auditors might be reluctant to change their opinion about a procedure resulting from their 
consultancy. In contrast, the provision of NASs together with the audit of financial statements could favour the audit process. These additional services contracted by clients will result in the auditor's having a more in-depth knowledge of the business.

The quality of auditors' work and their independence are important challenges to research in this topic (CHADEGANI; MOHAMED, 2014). Based on previous work set in countries with different characteristics, such as Wines (1994), Craswell (1999) and Firth (2002), among others, the opinion contained in the audit report was used in this research as a proxy for independence. Two proxies were used: the existence of a qualified opinion and a going-concern statement.

Brazil offers an environment unlike that of studies centred in developed economies. Because Brazil is considered a country offering weak legal protections to minority shareholders with ownership and control concentration, large shareholders' influence on management and relationship with auditors might compromise the independence of audit firms. Conversely, the regulatory obligation of switching auditors every five years reduces the threat to independence posed by the existence of a long-term relationship.

The results indicate that there is no reduction in auditor independence attributable to the provision of NASs. The findings are robust across the two different specifications of the independence proxy (qualified opinion and going concern), NASs (value of NASs and the ratio of non-audit/audit services values) and for a subsample of qualifiable companies (more indebted and with losses).

However, when the fees for NASs are summed with audit fees, our results show a negative and significant impact on independence for both proxies (qualified opinion and going concern) and in the subsample of qualifiable companies (with the going concern proxy for independence). This result may signal that it is not the type of service (audit or non-audit), but the total fees and the possible resulting economic dependence on the client that compromises independence. Cahan et al. (2008) result also finds a significant relationship between NAS and independence only in a specific subset in which NASs interacts with client importance.

The models contain controls for many other threats to independence mentioned in the literature. A long-term relationship (TENURE), being in the first two years of a contract (INITIAL) and being rehired after the cooling-off period (REHIRED) do not have a statistically significant relationship with proxies for independence.

In an environment such as Brazil, in which ownership and control concentration and their influence on management could represent threats to audit-firm independence, it is important to control for corporate governance characteristics that can minimise these effects. The research examined controls for rights mismatch (RIGHTMIS), being listed in a new market, the most demanding segment of BM\&FBOVESPA in terms of corporate governance (NM), having different persons as CEO and chairman of the board (CEO), having an audit committee (AUDCMT) and the percentage of independent board members (EXT).

In the models with a qualified report as a proxy for independence, the percentage of independent board members increases the propensity of this type of report. Contrary to expectations, however, having different persons in CEO and chairman of the board positions negatively impacts the probability of having a qualified report. Perhaps, the influence of controlling shareholders in pointing out these executives could mine the expected benefits. These findings are not maintained in versions of the model with going concern as the dependent variable or in the sub-sample of qualifiable companies.

This research contributes to the academic literature and is of interest to regulators, providing evidence of the relationship between the provision of NASs and the independence of the external auditor. 


\section{REFERENCES}

ANTLE, Rick. Auditor Independence. Journal of Accounting Research, v. 22, n. 1, p. 1-20, 1984.

ASHBAUGH, Hollis; LAFOND, Ryan; MAYHEW, Brian W. Do nonaudit services compromise auditor independence? Further evidence. The Accounting Review, v. 78, n. 3, p. $611+$, jul. 2003.

BARTON, Jan. Who Cares about Auditor Reputation? Contemporary Accounting Research, v. 22 , n. 3 , p. 549-586, 1 out. 2005.

BASIOUDIS, Ilias G.; PAPAKONSTANTINOU, Evangelos; GEIGER, Marshall A. Audit Fees, Non-Audit Fees and Auditor Going-Concern Reporting Decisions in the United Kingdom. Abacus, v. 44, n. 3, p. 284-309, set. 2008.

BUTLER, Marty; LEONE, Andrew J.; WILLENBORG, Michael. An empirical analysis of auditor reporting and its association with abnormal accruals. Journal of Accounting and Economics, v. 37, n. 2, p. 139-165, jun. 2004.

CAHAN, Steven et al. Non-audit fees, long-term auditor-client relationships and earnings management. Accounting \& Finance, v. 48, n. 2, p. 181-207, 1 jun. 2008.

CAHAN, Steven F. et al. Damaged Auditor Reputation and Analysts' Forecast Revision Frequency. AUDITING: A Journal of Practice \& Theory, v. 32, n. 1, p. 33-60, fev. 2013.

CALLAGHAN, Joseph; PARKASH, Mohinder; SINGHAL, Rajeev. Going-Concern Audit Opinions and the Provision of Nonaudit Services: Implications for Auditor Independence of Bankrupt Firms. Auditing: A Journal of Practice \& Theory, v. 28, n. 1, p. 153-169, maio 2009.

CAREY, Peter; KORTUM, Stuart; MORONEY, Robyn. Auditors' going-concern-modified opinions after 2001: measuring reporting accuracy. Accounting \& Finance, v. 52, n. 4, p. 1041-1059, dez. 2012.

CHADEGANI, Arezoo Aghaei; MOHAMED, Zakiah Muhammaddun. Reporting errors and misstatements: a measurement for the quality of auditors' work. Asian Journal of Business Ethics, v. 3, n. 1, p. 83-96, 1 mar. 2014.

CHEN, Shimin; SUN, Sunny Y. J.; WU, Donghui. Client Importance, Institutional Improvements, and Audit Quality in China: An Office and Individual Auditor Level Analysis. The Accounting Review, v. 85, n. 1, p. 127-158, jan. 2010.

COMISSÃO DE VALORES MOBILIÁRIOS - CVM. Instrução CVM no 480, de 7 de dezembro de 2009. Rio de Janeiro:, , 2009. Disponível em: <http://www.cvm.gov.br/asp/cvm www/Atos/Atos/inst/inst480consolid.doc>. Acesso em: 2 maio 2013.

CONSELHO FEDERAL DE CONTABILIDADE - CFC. Normas brasileiras de contabilidade: NBC PA - do auditor independente: NBC PA 01, 11, 12, 13, 290 e 291 e Resolução CFC 1.019/05. Brasília-DF, , 2012. Disponível em: <http://www.cvm.gov.br/asp/ cvmwww/Atos/Atos/inst/inst480consolid.doc>. Acesso em: 2 maio 2013. 
CONSELHO FEDERAL DE CONTABILIDADE - CFC. Resolução n. ${ }^{0} 1.374$ de 08 de Dezembro de 2011. Brasília-DF, , 2011. Disponível em: <http://www.cfc.org.br/sisweb/sr e/docs/RES_1374.doc>. Acesso em: 25 dez. 2012.

CRASWELL, Allen T. Does the Provision of Non-Audit Services Impair Auditor Independence? International Journal of Auditing, v. 3, n. 1, p. 29-40, mar. 1999.

CRASWELL, Allen T.; STOKES, Donald J.; LAUGHTON, Janet. Auditor independence and fee dependence. Journal of Accounting and Economics, v. 33, n. 2, p. 253-275, jun. 2002.

DAMASCENA, Luzivalda Guedes; PAULO, Edilson; CAVALCANTE, Paulo Roberto Nóbrega. Divergências entre Parágrafos de Ressalva e Parágrafos de Ênfase nos Pareceres de Auditoria. Revista de Contabilidade do Mestrado em Ciências Contábeis da UERJ, v. 16, n. 2 , p. 50-66, 18 out. 2011.

DANTAS, José Alves et al. Concentração de Auditoria no Mercado de Capitais Brasileiro. Revista de Contabilidade e Organizações, v. 6, n. 14, p. 4-21, 21 jun. 2012.

DEANGELO, Linda Elizabeth. Auditor size and audit quality. Journal of Accounting and Economics, v. 3, n. 3, p. 183-199, dez. 1981.

DEFOND, Mark L.; RAGHUNANDAN, K.; SUBRAMANYAM, K.r. Do Non-Audit Service Fees Impair Auditor Independence? Evidence from Going Concern Audit Opinions. Journal of Accounting Research, v. 40, n. 4, p. 1247-1274, 2002. Acesso em: 17 maio 2013.

DHALIWAL, Dan S. et al. Management Influence on Auditor Selection and Subsequent Impairments of Auditor Independence during the Post-SOX Period. Contemporary Accounting Research, v. 32, n. 2, p. 575-607, 1 jun. 2015.

DOPUCH, Nicholas; KING, Ronald R.; SCHWARTZ, Rachel. Independence in Appearance and in Fact: An Experimental Investigation. Contemporary Accounting Research, v. 20, n. 1, p. 79-114, 2003.

FIRTH, Michael. Auditor-Provided Consultancy Services and their Associations with Audit Fees and Audit Opinions. Journal of Business Finance \& Accounting, v. 29, n. 5\&6, p. 661693, jun. 2002.

FIRTH, Michael. The Provision of Nonaudit Services by Accounting Firms to their Audit Clients. Contemporary Accounting Research, v. 14, n. 2, p. 1-21, jun. 1997.

FRANCIS, Jere R.; KRISHNAN, Jagan. Accounting Accruals and Auditor Reporting Conservatism. Contemporary Accounting Research, v. 16, n. 1, p. 135-165, mar. 1999.

GEIGER, Marshall A.; RAGHUNANDAN, K. Auditor Tenure and Audit Reporting Failures. Auditing: A Journal of Practice \& Theory, v. 21, n. 1, p. 67-78, mar. 2002.

GRAMLING, Audrey A.; RITTENBERG, Larry E.; JOHNSTONE, Karla M. Auditoria. Tradução Antonio Zoratto Sanvicente. São Paulo: Cengage Learning, 2012. 
GRIFFIN, Paul A.; LONT, David H.; SUN, Yuan. Corporate Governance and Audit Fees: Evidence of Countervailing Relations. Journal of Contemporary Accounting \& Economics, v. 4, n. 1, p. 18-49, jun. 2008.

HAY, David; KNECHEL, Robert; LI, Vivian. Non-audit Services and Auditor Independence: New Zealand Evidence. Journal of Business Finance \& Accounting, v. 33, n. 5-6, p. 715734, jun. 2006.

JENSEN, Michael C.; MECKLING, William H. Theory of the firm: Managerial behavior, agency costs and ownership structure. Journal of Financial Economics, v. 3, n. 4, p. 305-360, out. 1976.

JOHNSON, E.; KHURANA, Inder K.; REYNOLDS, J. Kenneth. Audit-Firm Tenure and the Quality of Financial Reports. Contemporary Accounting Research, v. 19, n. 4, p. 637-660, 1 dez. 2002.

JOHNSTONE, Karla M.; WARFIELD, Terry D.; SUTTON, Michael H. Antecedents and Consequences of Independence Risk: Framework for Analysis. Accounting Horizons, v. 15, n. 1, p. 1-18, mar. 2001.

KRISHNAN, Jagan; KRISHNAN, Jayanthi; STEPHENS, Ray G. The Simultaneous Relation Between Auditor Switching and Audit Opinion: An Empirical Analysis. Accounting and Business Research, v. 26, n. 3, p. 224-236, 1 jun. 1996.

LI, Chan. Does Client Importance Affect Auditor Independence at the Office Level? Empirical Evidence from Going-Concern Opinions. Contemporary Accounting Research, v. 26, n. 1, p. 201-230, 1 abr. 2009.

MARTINEZ, Antonio Lopo; REIS, Graciela Mendes Ribeiro. Audit Firm Rotation and Earnings Management in Brazil. Revista de Contabilidade e Organizações, v. 4, n. 10, p. 4864, 1 dez. 2010.

MUTCHLER, Jane F.; HOPWOOD, William; MCKEOWN, James M. The influence of contrary information and mitigating factors in audit opinion decisions on bankrupt companies. Journal of Accounting Research, v. 35, n. 2, p. 295-310, 1997.

REYNOLDS, J.Kenneth; FRANCIS, Jere R. Does size matter? The influence of large clients on office-level auditor reporting decisions. Journal of Accounting and Economics, v. 30, n. 3, p. 375-400, dez. 2000. Acesso em: 19 maio 2013.

SHARMA, Divesh S.; SIDHU, Jagdish. Professionalism vs Commercialism: The Association Between Non-Audit Services (NAS) and Audit Independence. Journal of Business Finance \& Accounting, v. 28, n. 5-6, p. 563-594, jun. 2001.

SIMON, Daniel T.; FRANCIS, Jere R. The Effects of Auditor Change on Audit Fees: Tests of Price Cutting and Price Recovery. The Accounting Review, v. 63, n. 2, p. 255-269, abr. 1988.

SIMUNIC, Dan A. Auditing, Consulting, and Auditor Independence. Journal of Accounting Research, v. 22, n. 2, p. 679-702, 1984. 
STERNBERG, Lior; LEAL, Ricardo P. C.; BORTOLON, Patricia M. Affinities and agreements among major Brazilian shareholders. International Journal of Disclosure and Governance, v. 8, n. 3, p. 213-228, ago. 2011.

WATTS, Ross L.; ZIMMERMAN, Jerold L. Agency Problems, Auditing, and the Theory of the Firm: Some Evidence. Journal of Law and Economics, v. 26, n. 3, p. 613-633, 1 out. 1983.

WATTS, Ross L.; ZIMMERMAN, Jerold L. Positive Accounting Theory. Englewood Cliffs: Prentice Hall, 1986.

WATTS, Ross L.; ZIMMERMAN, Jerold L. The Markets for Independence and Independent Auditors. , Working Paper. Center for Research in Governement Policy \& Business: Graduate School of Management, University of Rochester, 1981. Disponível em: <http://hdl.handle.net/1802/4903>. Acesso em: 19 dez. 2013.

WINES, Graeme. Auditor Independence, Audit Qualifications and the Provision of Non-Audit Services: A Note. Accounting \& Finance, v. 34, n. 1, p. 75-86, 25 fev. 1994. 